\title{
80세 이상 고령에서 시행한 특발망막앞막제거술의 임상결과 Clinical Outcomes of Idiopathic Epiretinal Membrane Removal in Patients 80 Years or Older
}

\author{
한재욱 · 김종우 · 김철구 · 이동원 · 유수진 · 최문정 · 유영주 · 김형석 · 조한주 · 김주연 · 김재휘 \\ Jae Wook Han, MD, Jong Woo Kim, MD, Chul Gu Kim, MD, Dong Won Lee, MD, Su Jin Yoo, MD, \\ Moon Jung Choi, MD, Young Ju Lew, MD, Hyung Seok Kim, MD, Han Joo Cho, MD, Ju Yeon Kim, MD, \\ Jae Hui Kim, MD \\ 건양대학교 의과대학 김안과병원 안과학교실 \\ Department of Ophthalmology, Kim's Eye Hospital, Konyang University College of Medicine, Seoul, Korea
}

\begin{abstract}
Purpose: To evaluate clinical outcomes of idiopathic epiretinal membrane removal in patients $\geq 80$ years of age.
Methods: A retrospective review of medical records was performed with 56 patients who underwent vitrectomy and removal of idiopathic epiretinal membrane. In the $\geq 80$ years of age group $(n=28)$, the best-corrected visual acuity (BCVA) and central macular thickness (CMT) before surgery were compared with those at the final follow-up. The amount of change in the BCVA after surgery was also compared between the $\geq 80$ years of age group and the $<80$ years of age group $(n=28)$.

Results: In the $\geq 80$ years of age group, the mean follow-up period was $19.1 \pm 17.0$ months. Before surgery, 11 eyes were pseudophakic and 17 eyes were phakic. Combined cataract surgery was performed with epiretinal membrane removal in all 17 phakic eyes. The mean logarithm of the minimal angle of resolution BCVA was $0.75 \pm 0.30$ before surgery, which improved to $0.50 \pm$ 0.30 at the final follow-up $(p<0.001)$. The CMT was $458.0 \pm 79.7 \mu \mathrm{m}$ before surgery, which decreased to $367.2 \pm 83.4 \mu \mathrm{m}$ at the final follow-up $(p<0.001)$. There was no significant difference in the amount of change in the BCVA after the surgery between the $\geq 80$ years of age group and the $<80$ years of age group $(p=0.547)$.

Conclusions: In patients with idiopathic epiretinal membrane who were $\geq 80$ years of age, the visual acuity was improved or maintained, and was accompanied with anatomical improvement after epiretinal membrane removal with or without cataract surgery. These results suggest the usefulness of epiretinal membrane removal in older patients.
\end{abstract}

J Korean Ophthalmol Soc 2020;61(2):159-166

Keywords: Epiretinal membrane, Epiretinal membrane removal, Old

망막앞막은 국내 40 세 이상의 성인에서 유병률 $2.9 \%$ 로 비교적 흔하게 관찰되는 질환으로 나이가 증가함에 따라

- Received: 2019. 1. 3.

- Revised: 2019. 3. 11.

- Accepted: 2020. 1. 17.

- Address reprint requests to Kim Jae Hui, MD

Kim's Eye Hospital, \#136 Yeongsin-ro, Yeongdeungpo-gu,

Seoul 07361, Korea

Tel: 82-2-2671-7665, Fax: 82-2-2671-6359

E-mail:kjh7997@daum.net

* Conflicts of Interest: The authors have no conflicts to disclose.
그 유병률도 증가하는 것으로 알려져 있다. ${ }^{1}$ 일반적으로 망 막앞막은 진행이 빠르지 않고, 심각한 시력 손상을 유발하 는 경우는 흔하지 않은 것으로 알려져 있다. ${ }^{2}$ 따라서 망막 앞막이 진단되어도 수술 없이 경과 관찰만 시행하는 경우 도 많다. 그러나 지속적으로 진행하며, 뚜렷한 시력의 손상 을 유발하는 경우 수술이 필요한데, 과거 여러 연구자들은 수술을 통해 망막앞막을 제거하면 시력을 유지하거나 회복 할 수 있다고 보고하였다. ${ }^{3-6}$

망막앞막수술은 일반적으로 수술 시간이 길지 않고, 국 소마취하에서 시행할 수 있는 경우도 많아 다양한 연령대 
의 환자를 대상으로 광범위하게 시행되는 수술이며, 수술 에 대한 특별한 금기 사항은 따로 정립되어 있지 않다. 그 러나 초고령 환자들의 경우 망막앞막이 진행하여 시력이 저하된 상태라 하더라도 단순히 눈 상태만 고려하는 것이 아니라 환자의 전신 상태와 기대여명 등에 대해 환자/보호 자와 충분히 상담 후 수술을 결정해야 하는 경우도 있다. 현재까지 망막앞막의 수술 결과에 대한 많은 연구들이 발 표되었으나 연구들에 포함된 환자의 대부분은 80 세 미만이 었으며, ${ }^{3,47}$ 보다 고령의 환자들에서의 수술 결과를 세부적 으로 분석한 연구는 없었다.

고령에서의 수술 결과에 대한 자료는 고령 환자에 대한 수술 여부를 결정함에 있어서 환자/보호자 상담 시 유용하 게 이용될 수 있을 것이다. 이에 본 연구에서는 80 세 이상 초고령 환자에서 특발망막앞막제거술의 임상성적을 보고 하고자 한다.

\section{대상과 방법}

본 후향적 연구는 단일 기관에서 헬싱키선언에 입각하여 시행되었으며, Institutional Review Board (IRB) 승인을 획 득하였다(Kim's Eye Hospital IRB 2019-3005). 2013년 6월 부터 2016년 12월까지 특발망막앞막으로 유리체절제술 및 망막앞막제거술을 시행 받은 환자들 중 80세 이상이었던 환자 28명(28안)을 대상으로 의무기록을 분석하였다.

다음과 같은 경우 연구에서 제외하였다: 1) 백내장수술 을 제외한 안내 수술 병력, 2) 각막혼탁 등 시기능에 영향 을 미칠 수 있는 다른 안구 이상 소견, 3) 유리체망막 질환 으로 치료받은 병력이 있는 경우. 수술은 구후마취 혹은 전 신마취 후 시행하였다. 23 게이지 평면부 유리체절제술 후 망막앞막을 제거하였으며, 술자의 판단에 따라 내경계막제 거술을 추가로 시행하였다. 또한 술자의 판단에 따라 보다 원활한 수술을 위해 트리암시놀론 혹은 인도사이아닌그린 용액을 이용하였다. 백내장이 함께 진단된 환자의 경우 의
사의 판단에 따라 유리체절제술과 함께 백내장수술을 시행 하였다. 백내장수술은 $2.8 \mathrm{~mm}$ 의 투명각막절개를 이용한 수정체유화술 후 접힘인공수정체삽입술을 시행하는 방식 으로 진행되었다.

수술 중 혹은 수술 후의 합병증 유무를 확인하였으며, 수 술 전 측정된 시력과 중심망막두께를 최종 추적 관찰 시의 값과 서로 비교하였다. 백내장수술을 함께 시행 받은 군과 망막앞막제거술만 시행 받은 군 사이의 시력 변화 정도를 추가적으로 비교하였다. 중심망막두께는 빛간섭단층촬영 결과를 이용하여 중심와에서 내경계막으로부터 브루크막 까지의 거리를 수동으로 측정하였으며, 시력은 logarithm of minimal of resolution (logMAR) 값으로 변환 후 분석하였 다. 빛간섭단층촬영에는 3 개의 기기가 이용되었다; Spectralis HRA-OCT $^{\circledR}$ (Heidelberg Engineering, Heidelberg, Germany), RS $3000^{\circledR}$ (Nidek Co., Ltd., Tokyo, Japan), SLO-OCT ${ }^{\circledR}$ (Ophthalmic Technologies Inc [OTI], Toronto, Canada).

추가적으로 술 전 시행된 빛간섭단층촬영 결과를 바탕으 로 원뿔세포외절말단선(Cone outer segment tip line)의 결 손과 내망막불규칙성 지수(inner retinal irregularity index) 가 시력예후에 미치는 영향을 평가하였다. 내망막불규칙성 지수의 경우 Cho et $\mathrm{al}^{8}$ 의 방법을 이용하여 측정하였다(Fig. 1). 중심와를 중심으로 수평, 수직으로 시행한 빛간섭단층촬영 결과에서 중심 $3,000 \mu \mathrm{m}$ 범위를 확인한 후 상기 범위 내에 내망상층(inner plexiform layer) 아래쪽 경계부의 길이와 망막색소상피층의 길이를 측정하였다. 이후 '내망상층 아 래쪽 경계부 길이/망막색소상피층의 길이'를 계산하여 이 를 내망막불규칙성 지수로 정의하였다. ${ }^{8}$ 이미지 분석은 Image $\mathrm{J}$ software (National Institute of Health, Bethesda, MD, USA) 프로그램을 이용하였으며, 수평, 수직 빛간섭단층촬영 결과 에서 측정된 값의 평균값을 결과 분석에 이용하였다. 내망 막불규칙성 지수와 술 전 시력, 술 후 최종추적 관찰 시 측 정된 시력, 및 시력의 변화량 사이의 연관관계를 분석하였 으며, 원뿔세포외절말단선이 관찰된 경우와 그렇지 않았던
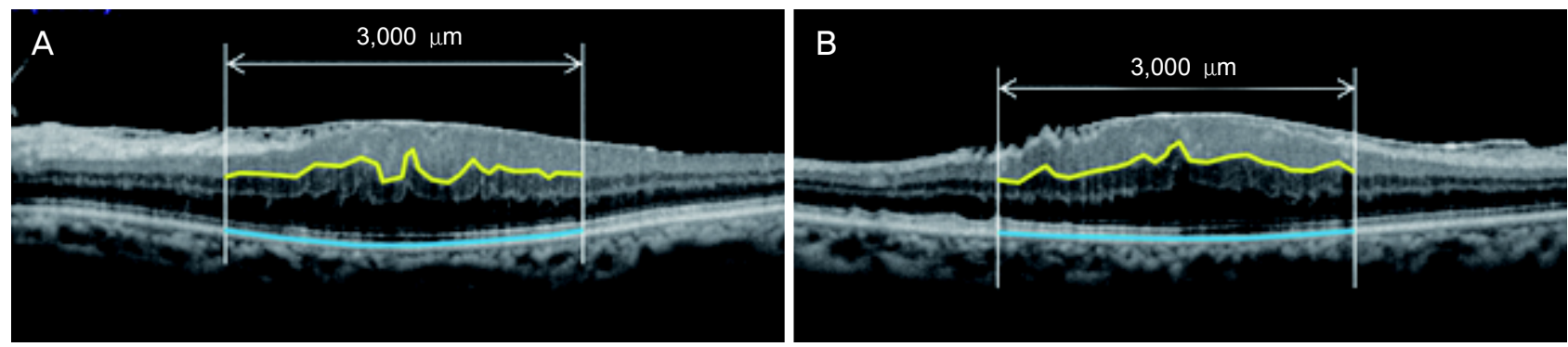

Figure 1. Horizontal (A) and vertical (B) optical coherence tomography scan images showing method to measure inner-retinal irregularity index. The yellow line indicates inferior border of inner plexiform layer (IPL) and the blue line indicates retinal pigment epithelium (RPE). The inner-retinal irregularity index was calculated as length of inferior border of IPL/length of RPE. 
경우 사이에 술 전 시력, 술 후 최종추적 관찰 시 측정된 시력, 및 시력의 변화량을 서로 비교하였다.

수술과 관련된 환자의 전신 상태 변화를 확인하기 위해 아래와 같은 분석을 추가로 시행하였다. 수술 전 병동에서 의 혈압 측정값을 수술장에서 수술 시행 직전 측정한 값, 수술 중 측정된 최대값, 수술 직후 병동에서 측정한 값과 서로 비교하였다. 혈압은 수축기 혈압과 이완기 혈압을 따 로 분석하였다. 병동에서의 다른 전신 이상 발생 여부와 평 균 입원 기간을 확인하였다.

2013년 6월부터 2016년 12월까지 특발망막앞막으로 망 막앞막제거술을 시행 받은 80 세 미만 환자, 80 세 이상 환자 중 백내장 및 망막앞막으로 진단되었으나 망막앞막에 대한 수술 없이 백내장수술만 시행한 환자, 80 세 이상 환자 중 망막앞막으로 진단되었으나 수술 없이 경과 관찰한 환자의 시력 및 해부학적 결과를 추가로 확인하였으며, 이들 세 군 을 대조군으로 하여 아래와 같은 분석을 시행하였다. 1) 망 막앞막제거술을 시행 받은 80세 미만 환자의 수술 전 및 마 지막 추적 관찰 시의 시력 변화량과 중심망막두께 변화량 을 80세 이상 군과 서로 비교, 2) 망막앞막에 대한 수술 없 이 백내장수술만 시행한 안과 80 세 이상 군에서 망막앞막 수술 및 백내장수술을 함께 시행한 안 사이의 수술 전 및 최종 추적 관찰 시의 시력 변화량, 술 전 중심망막두께 및 내망막불규칙성 지수를 서로 비교, 3) 망막앞막에 대한 수 술 없이 경과 관찰한 안과 백내장수술 없이 망막앞막수술 만 시행한 안 사이에 진단 시 및 최종 추적 관찰 시의 시력 변화량을 서로 비교하여 분석하였다. 연구기간 내에 진단 혹은 수술을 받은 환자들 중 진단 혹은 수술일이 빠른 순서 대로 각 군당 28 명(28안)이 대조군으로 선정되었다.

통계 분석에는 SPSS 프로그램(SPSS ver. 12.0 for Windows; SPSS Inc., Chicago, IL, USA)을 이용하였다. Paired $t$-test 를 이용하여 서로 다른 두 시점에 측정된 값을 비교하였으 며, independent samples $t$-test를 이용하여 서로 다른 두 군 사이의 값을 비교하였다. 서로 다른 네 시점에 측정된 값의 경우 repeated-measures analysis of variances with Bonferroni's method를 이용하여 비교하였다. 연관관계 분석은 Pearson correlation analysis를 이용하였다. 0.05 미만의 $p$ 값을 통계 적으로 유의한 값으로 정의하였다.

\section{결 과}

Table 1은 연구에 포함된 80 세 이상 28명(28안)의 특성 을 보여주며, Fig. 2는 대표 증례를 보여준다. 남성 6명, 여 성 22명이었으며, 평균 연령은 $83.4 \pm 2.2$ 세(80-88세)였다. 수술 전 11 명은 위수정체, 17 명은 유수정체였으며, 유수정 체였던 환자 17명 모두에서 망막앞막제거술과 백내장수술 을 함께 시행하였다. 구후마취를 받은 경우는 23 명, 전신마 취를 받은 경우는 5 명이었으며, 5 명에서는 후유리체박리와 망막앞막의 제거를 위해 트리암시놀론 염색을 시행하였다. 내경계막 제거는 24 명에서 시행되었는데, 이들 24 명 중 20 명 에서는 $0.125 \%$ 인도사이아닌그린 용액을 유리체강 내로 주입하여 내경계막에 대한 염색을 시행한 후 내경계막제거 술을 시행하였다. 수술 중 망막열공의 발생과 같은 합병증 은 없었으며, 백내장수술 도중 후낭파열이 발생한 안은 없 었다. 수술 후 안내염이나 망막박리, 안압상승과 같은 합병

Table 1. Baseline characteristics of patients $\geq 80$ years of age

\begin{tabular}{lc}
\hline Characteristic & Value $(\mathrm{n}=28)$ \\
\hline Age (years) & $83.4 \pm 2.2$ \\
Sex (male:female) & $6: 22$ \\
Hypertension & $17(60.7)$ \\
Diabetes mellitus & $4(14.3)$ \\
Other systemic disorders & \\
Angina pectoris & $2(7.1)$ \\
Depression & $1(3.6)$ \\
Phakia:pseudophakia & $17: 11$ \\
Best-corrected visual acuity $(\operatorname{logMAR})$ & $0.75 \pm 0.30$ \\
Central foveal thickness $(\mu \mathrm{m})$ & $458.0 \pm 79.7$ \\
\hline
\end{tabular}

Values are presented as mean \pm standard deviation or number (\%) unless otherwise indicated.

LogMAR $=$ logarithm of minimal angle of resolution.
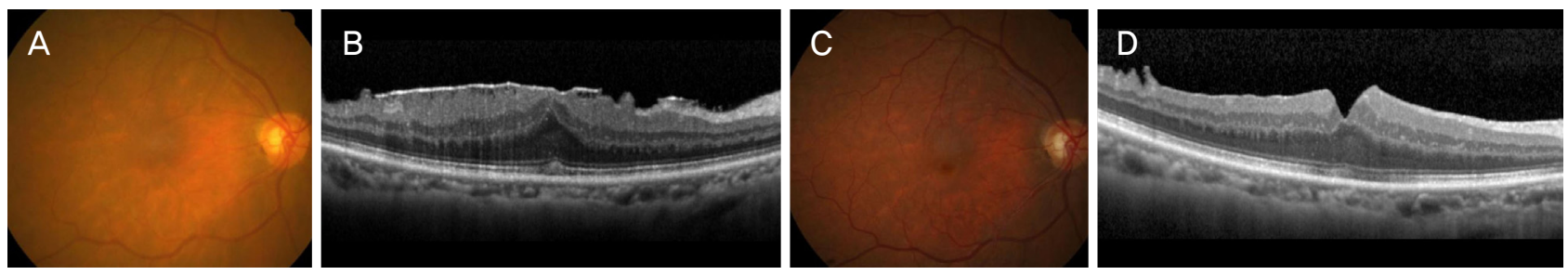

Figure 2. Outcomes of 84-year-old patient who was diagnosed with epiretinal membrane and cataract. The best-corrected visual acuity (BCVA) was 0.2 (decimal) before surgery (A, B). The patients underwent combined epiretinal membrane removal and cataract surgery. Five months after the surgery $(C, D)$, the BCVA improved to 0.4 (decimal). 
증은 관찰되지 않았으며, 수술 후 3 개월간 전신적인 합병증 이 발생한 경우는 없었다. 수술 후 평균 추적 관찰기간은 $19.1 \pm 17.0$ 개월이었다.

수술 전 측정된 평균 $\log \mathrm{MAR}$ 시력은 $0.75 \pm 0.30$ 이었으 며, 수술 후 최종 추적 관찰 시 $0.50 \pm 0.30$ 으로 호전되었다 $(p<0.001)$ (Fig. 3A). 전체 28안 중 27안(96.4\%)에서 시력이 유지되거나 호전되었으며, 17 안(60.7\%)의 경우 $\log \mathrm{MAR}$ 0.2 이상의 시력호전이 나타났다(Table 2). 백내장수술을 함께 시행 받은 군 $(\mathrm{n}=17)$ 의 경우 평균 추적 관찰기간은 $17.2 \pm 16.3$ 개월이었으며, 수술 전 및 최종 추적 관찰 시의 평균 $\log \mathrm{MAR}$ 시력은 각각 $0.77 \pm 0.31,0.44 \pm 0.32$ 로 측정 되었다(Fig. 3B). LogMAR 0.2 이상의 시력호전은 13 안에 서 나타났으며, $\operatorname{logMAR} 0.2$ 이상의 시력악화를 보인 안은 없었다. 망막앞막수술 전 이미 위수정체안으로 망막앞막수 술만 시행 받은 군 $(\mathrm{n}=11)$ 의 경우 평균 추적 관찰기간은 $22.1 \pm 18.3$ 개월이었으며, 수술 전 및 최종 추적 관찰 시의 평균 $\operatorname{logMAR}$ 시력은 각각 $0.72 \pm 0.28,0.58 \pm 0.25$ 였다 (Fig. 3B). LogMAR 0.2 이상의 시력호전은 4 안에서 나타 났으며, $\operatorname{logMAR} 0.2$ 이상의 시력악화를 보인 안은 없었다. 백내장수술을 함께 시행 받은 군에서 망막앞막수술만 시행 받은 군에 비해 유의하게 더 큰 폭의 시력호전이 나타났다 $(p=0.041)$.

중심망막두께는 수술 전 $458.0 \pm 79.7 \mu \mathrm{m}$ 였으며, 최종 추 적 관찰 시 $367.2 \pm 83.4 \mu \mathrm{m}$ 로 감소하였다 $(p<0.001)$ (Fig. $4 \mathrm{~A})$. 백내장수술을 함께 시행 받은 군(n=17)의 경우 수술 전 및 최종 추적 관찰 시의 평균 중심망막두께는 $461.1 \pm 81.1 \mu \mathrm{m}$, $377.3 \pm 80.6 \mu \mathrm{m}$ 였으며, 망막앞막수술만 시행 받은 군 $(\mathrm{n}=11)$ 의 경우 그 값은 각각 $453.3 \pm 81.2 \mu \mathrm{m}, 351.6 \pm 89.3 \mu \mathrm{m}$ 였 다(Fig. $4 \mathrm{~B})$. 양 군 사이의 중심망막두께 변화 정도에는 유
의한 차이가 없었다 $(p=0.373)$.

수축기 혈압의 경우 수술 전 병동에서 $135.5 \pm 11.7 \mathrm{mmHg}$, 수술장에서 수술 시행 직전 $158.2 \pm 21.6 \mathrm{mmHg}$, 수술 중 최대 $156.3 \pm 26.9 \mathrm{mmHg}$, 수술 직후 병동에서 $144.1 \pm$ $14.1 \mathrm{mmHg}$ 로 측정되었다. 수술 전 측정한 값에 비해 수술 시행 직전 값 $(p=0.006)$ 및 수술 중 최대값 $(p=0.029)$ 은 유의 하게 더 높았으나 수술 직후 측정한 값은 차이가 없었다 $(p=0.132)$. 이완기 혈압의 경우 수술 전 병동에서 $77.2 \pm$ $9.1 \mathrm{mmHg}$, 수술장에서 수술 시행 직전 $83.1 \pm 9.0 \mathrm{mmHg}$, 수술 중 최대 $80.1 \pm 14.7 \mathrm{mmHg}$, 수술 직후 병동에서 78.7 $\pm 10.6 \mathrm{mmHg}$ 로 측정되었다. 수술 전 측정한 값에 비해 수 술 시행 직전 값 $(p=0.353)$, 수술 중 최대값 $(p=1.000)$ 및 수 술 직후 측정한 값 $(p=1.000)$ 사이에는 유의한 차이가 없었 다. 평균 입원 기간은 $3.5 \pm 0.5$ 일이었으며, 입원 기간 중 전신 이상은 나타나지 않았다.

술 전 평균 내망막불규칙성 지수는 $1.20 \pm 0.15$ 로 측정되 었다. 전체 28 안을 대상으로 분석하였을 때, 내망막불규칙 성 지수는 술 전 시력과는 유의한 연관관계가 있었으나 $(p=0.044, \mathrm{r}=0.381)$, 술 후 최종추적 관찰 시의 시력 $(p=0.068)$

Table 2. Amount of change in best-corrected visual acuity after surgery

\begin{tabular}{lc}
\hline Grade $(\operatorname{logMAR})$ & Number of patients $(\mathrm{n}=28)$ \\
\hline Improvement $\geq 0.2$ & $17(60.7)$ \\
Improvement $<0.2$ & $5(17.9)$ \\
No change & $5(17.9)$ \\
Deterioration $<0.2$ & $1(3.6)$ \\
Deterioration $\geq 0.2$ & 0 \\
\hline
\end{tabular}

Values are presented as number (\%).

$\operatorname{LogMAR}=$ logarithm of minimal angle of resolution.
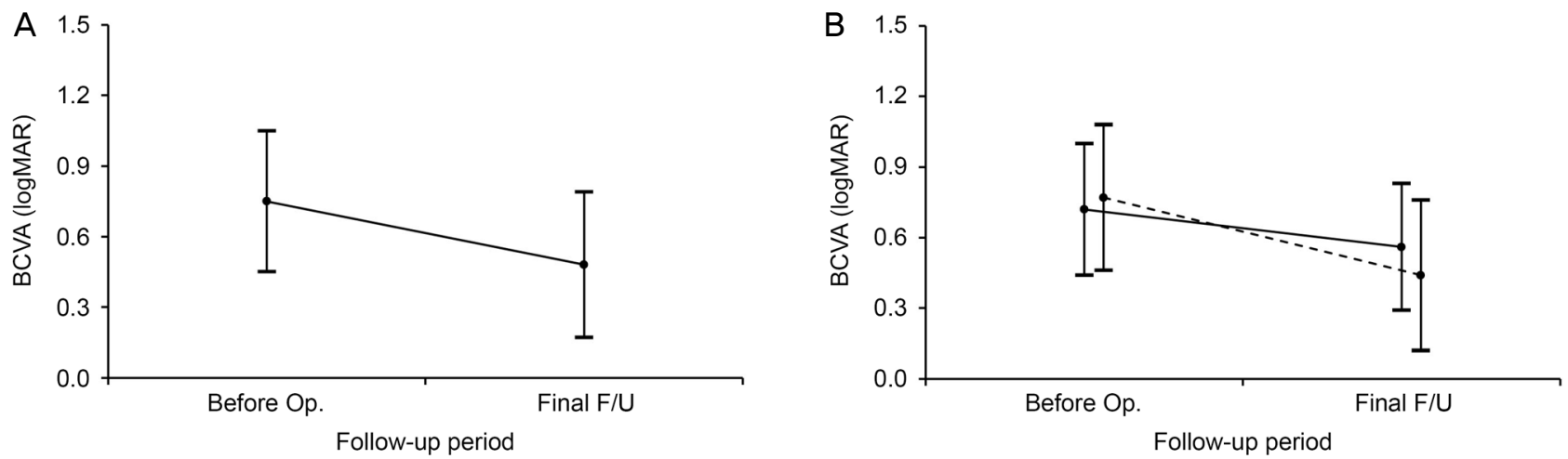

Figure 3. Changes in logarithm of minimal angle of resolution (logMAR) best-corrected visual acuity (BCVA) of patients who underwent epiretinal membrane removal with or without cataract surgery. There was a significant improvement in BCVA after surgery $(p<0.001)$. (A) Outcomes in all 28 patients. (B) Comparison of outcome between patients who underwent epiretinal membrane removal only (solid line, $\mathrm{n}=11$ ) and patients who underwent combined epiretinal membrane removal and cataract surgery (dotted line, $\mathrm{n}=17)$. $\mathrm{Op}=$ operation; $\mathrm{F} / \mathrm{U}=$ follow-up. 
혹은 시력의 변화량 $(p=0.873)$ 과는 유의한 연관관계가 나타 나지 않았다. 술 전 7안에서 원뿔세포외절말단선의 결손이 발견되었다. 양 군 사이에 술 전 시력 $(p=0.351)$, 술 후 시력 $(p=0.287)$ 및 시력의 변화량 $(p=0.837)$ 사이에 유의한 차이 는 없었다.

망막앞막수술을 시행받은 80세 미만 환자 28명(Table 3) 의 경우 평균 연령은 $60.7 \pm 8.4$ 세였으며, 13 안에서 백내장 수술을 함께 시행하였다. 수술 후 평균 추적 관찰기간은 $19.0 \pm 8.0$ 개월이었다. 평균 $\log \mathrm{MAR}$ 시력은 술 전 $0.48 \pm$ 0.22 , 최종 추적 관찰 시 $0.26 \pm 0.18$ 로 측정되었다. 평균 중 심망막두께는 술 전 $475.3 \pm 89.5 \mu \mathrm{m}$, 최종 추적 관찰 시 $370.8 \pm 73.5 \mu \mathrm{m}$ 였다. 80세 이상 군과 비교하였을 때, 양 군 사이에 시력 $(p=0.547)$ 및 중심망막두께 변화량 $(p=0.838)$ 의 유의한 차이는 나타나지 않았다. 수술 후 3 개월간 전신 적인 합병증이 발생한 경우는 없었다.

망막앞막 및 백내장으로 진단되었으나 망막앞막수술 없 이 백내장수술만 시행한 28안(Table 3)의 경우 수술 후 평
균 추적 관찰기간은 $19.0 \pm 8.0$ 개월이었다. 술 전 평균 중심 망막두께는 $380.0 \pm 82.8 \mu \mathrm{m}$, 평균 내망막불규칙성 지수는 $1.13 \pm 0.07$ 이었으며, 평균 $\log \mathrm{MAR}$ 시력은 술 전 $0.61 \pm 0.29$ 에서 최종 추적 관찰 시 $0.32 \pm 0.21$ 로 변화하였다. 80 세 이 상 군에서 백내장수술과 망막앞막수술을 함께 시행한 17 안 과 비교하였을 때, 수술을 함께 시행 받은 경우 시력 회복 이 조금 더 큰 폭으로 나타났으나(평균 $0.33 \pm 0.29$ vs. 0.29 $\pm 0.29)$ 양 군 간의 차이는 유의하지 않았으며 $(p=0.556)$, 내 망막불규칙성 지수 $(p=0.071)$ 역시 유의한 차이는 없었다. 그러나 술 전 중심망막두께의 경우(평균 $464.8 \pm 79.7 \mu \mathrm{m}$ vs. $380.0 \pm 82.8 \mu \mathrm{m})$ 백내장만 시행한 군에서 유의하게 더 적은 값을 보였다 $(p=0.002)$.

망막앞막으로 진단되었으나 수술 없이 추적 관찰한 28 안 (Table 3)의 경우 평균 연령은 $82.9 \pm 2.3$ 세였으며, 진단 후 $16.2 \pm 14.4$ 개월 간 추적 관찰하였다. 최초 진단 시의 중심 망막두께는 $428.0 \pm 98.8 \mu \mathrm{m}$ 였다. 최초 진단 시 평균 $\operatorname{logMAR}$ 시력은 $0.39 \pm 0.29$ 였으며, 최종 추적 관찰 시에는 $0.42 \pm$
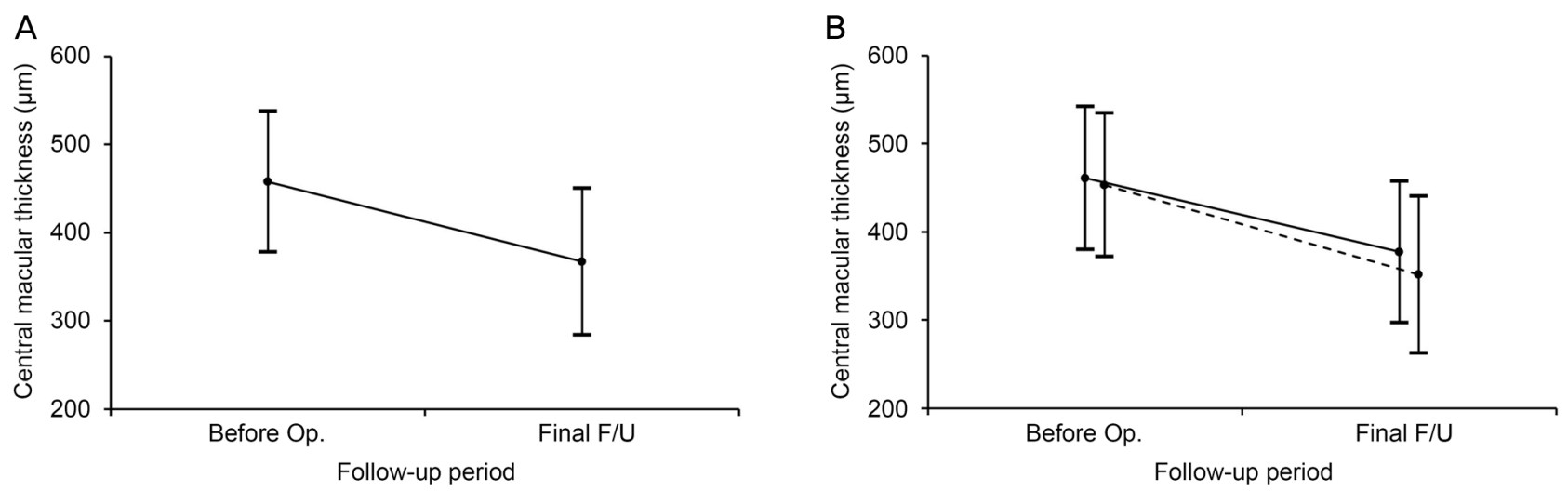

Figure 4. Changes in central macular thickness of patients who underwent epiretinal membrane removal with or without cataract surgery. There was a significant decrease in central macular thickness after surgery $(p<0.001)$. (A) Outcomes in all 28 patients. (B) Comparison of outcome between patients who underwent epiretinal membrane removal only (solid line, $\mathrm{n}=11$ ) and patients who underwent combined epiretinal membrane removal and cataract surgery (dotted line, $\mathrm{n}=17$ ).

Table 3. Baseline characteristics of patients included in the control groups

\begin{tabular}{lccc}
\hline Characteristic & $\begin{array}{c}\text { Patients }<80 \text { years who } \\
\text { underwent ERM removal } \\
(\mathrm{n}=28)\end{array}$ & $\begin{array}{c}\text { Patients } \geq 80 \text { years who } \\
\text { underwent cataract surgery only } \\
(\mathrm{n}=28)\end{array}$ & $\begin{array}{c}\text { Patients } \geq 80 \text { years who } \\
\text { followed-up without surgery } \\
(\mathrm{n}=28)\end{array}$ \\
\hline Age (years) & $60.7 \pm 8.4$ & $83.2 \pm 2.9$ & $82.9 \pm 2.3$ \\
Sex (male:female) & $11: 17$ & $9: 19$ & $12: 16$ \\
Hypertension & $15(53.6)$ & $15(53.6)$ & $17(60.7)$ \\
Diabetes mellitus & $4(14.3)$ & $5(17.9)$ & $4(14.3)$ \\
Phakia:pseudophakia & $24: 4$ & $28: 0$ & $9: 19$ \\
Best-corrected visual acuity (logMAR) & $0.48 \pm 0.22$ & $0.61 \pm 0.29$ & $0.39 \pm 0.29$ \\
Central foveal thickness $(\mu \mathrm{m})$ & $475.3 \pm 89.5$ & $380.0 \pm 82.8$ & $428.0 \pm 98.8$ \\
\hline
\end{tabular}

Values are presented as mean \pm standard deviation or number $(\%)$ unless otherwise indicated.

$\mathrm{ERM}=$ epiretinal membrane; logMAR $=$ logarithm of minimal angle of resolution. 
0.30 으로 측정되었다. 고령에서 백내장수술 없이 망막앞막 수술만 시행받은 11 안과 비교하였을 때, 양 군 간에 시력 변화는 유의한 차이가 있었다 $(p=0.015)$.

\section{고 찰}

망막앞막은 세포성 혹은 비세포성 바탕질(matrix)로 구성 되어 있는데, 세포성 요소가 근섬유모세포(myofibroblast) 로 분화하면서 수축성 막의 형태로 바뀔 수 있다. ${ }^{9}$ 나이에 따라 그 유병률이 증가하는 것으로 알려져 있는데, 국내 환 자를 대상으로 한 Kim et $\mathrm{al}^{1}$ 의 연구에 따르면 40대의 경우 그 유병률이 $12.5 \%$ 에 불과하였으나 70 대 이상의 경우 $30.6 \%$ 까지 상승하였다. 망막앞막은 후유리체박리가 진행된 안에 서 주로 발생하는 것으로 알려져 있기에, 나이에 따른 이러 한 유병률 증가는 후유리체박리 빈도 증가와 관련 있을 것 으로 추측되었다. ${ }^{1}$

망막앞막은 느리지만 진행성을 가지는 질환으로 일부 환 자에서는 뚜렷한 시력의 저하가 나타날 수 있다. ${ }^{2}$ 막이 자 연적으로 망막에서 떨어지는 경우도 있으나 ${ }^{10}$ 이는 드문 경 우이며, 거의 대부분에서는 수술 없이는 치료가 어렵다. 따 라서 망막앞막을 수술한다는 것은 당장 시력을 회복시킬 수도 있다는 점뿐 아니라 장기적으로 점진적인 시력저하의 가능성을 낮출 수 있다는 데에도 그 의의가 있다. 특히 80 대 의 고령의 환자를 대상으로 망막앞막을 수술한다는 것은 오히려 후자, 즉, 향후 추가적인 시력저하의 가능성을 낮추 어 준다는 부분에 더 큰 의미를 부여할 수도 있을 것으로 생각되는데, 왜냐하면 시간이 지나면서 시력저하가 지속된 다 하더라도 고령으로 인해 수술을 결정하기가 보다 어려 워질 수 있기 때문이다. 비록 90세 이상의 초고령에서도 유 리체망막수술을 성공적으로 시행할 수 있다는 보고가 있으 나 $^{11}$ 환자의 전신 상태나 기대여명 등을 고려하였을 때, 90 세 이상의 환자에서 망막앞막수술을 적극적으로 권유하기는 쉽지 않은 경우가 많다. 또한, 비록 망막앞막수술이 안전한 수술이라 하더라도 유리체절제술의 일반적인 합병증인 안 내염, ${ }^{12}$ 망막박리, ${ }^{13}$ 녹내장 ${ }^{14}$ 등이 발생할 수 있는데, 이러 한 합병증 발생 시 초고령의 환자에서는 처치가 수월하지 않을 수 있다.

망막앞막제거술의 결과에 대해서는 기존에 많은 연구 가 이루어졌으나 연구에 포함된 환자들의 평균연령은 약 63-76세 정도였다. ${ }^{3-6,15}$ 보다 고령의 환자에서의 수술 결과 는 아직 잘 알려져 있지 않으나 기존의 연구에 따르면 망막 앞막제거술의 결과는 환자 연령과 유의한 연관관계가 나타 나지 않았다. ${ }^{16}$ 실제 본 연구에서도 수술 후의 시력 변화 및 중심망막두께의 변화 정도는 80 세 이상 환자군과 80 세 미
만 환자군 사이에 유의한 차이가 없었다. 또한 비록 수술 시 수축기 혈압의 상승이 관찰되기는 하였으나 수술 직후 다시 호전되었으며, 관련된 전신 이상은 나타나지 않았다. 따라서 고연령 환자라 할지라도 연령적인 측면을 특별히 더 고려하지 않고 보다 젊은 환자에서와 같은 판단 기준을 이용하여 수술을 고려해 볼 수 있을 것이다. 본 연구는 고 연령 환자만을 대상으로 하였으며, 따라서 상기 환자군에 보다 직접적으로 관련된 정보를 제공할 수 있을 것으로 생 각된다. 이러한 정보는 특히 환자/보호자에게 수술 관련 설 명을 할 때 유용하게 이용될 수 있을 것이다.

본 연구는 80 세 이상 고령에서의 망막앞막수술 결과를 분석하여 보고한 최초의 연구이다. 술 후 평균 $19.1 \pm 17.0$ 개 월의 추적 관찰기간 동안 전체 환자의 $64.3 \%$ 에서 $\log \mathrm{MAR}$ 0.2 이상의 시력호전이 나타났으며, 나머지 $35.7 \%$ 에서도 시력이 유지되는 결과를 보였다. 시력호전의 정도는 백내 장수술을 같이 시행한 17 안에서 상대적으로 큰 폭으로 나 타나는 경향이 있었다. 국민건강영양조사 결과에 따르면 국내 백내장 유병률은 연령에 따라 증가하여, 65 세 이상에 서는 $88 \%$ 에 달하는 것으로 나타났다. ${ }^{17}$ 따라서 고령 망막 앞막환자의 경우 기존에 백내장수술을 시행 받지 않은 경 우라면 백내장이 함께 진단되는 빈도가 높을 것으로 생각 되는데, 이러한 경우 망막앞막수술만 진행하게 되면 이후 백내장이 보다 빠른 속도로 진행하여 시력저하가 발생할 수 있는 것으로 알려져 있다. ${ }^{18}$ 망막앞막과 백내장이 함께 진단되는 경우 망막앞막제거술을 먼저 시행한 후 백내장수 술을 나중에 시행할 수도 있지만 망막앞막제거술과 백내장 수술을 동시에 시행할 수도 있는데, Jung et $\mathrm{al}^{19}$ 의 연구에 따르면 두 방법 모두 비슷한 정도의 시력회복을 보인 것으 로 나타났다. 본 연구에서는 백내장이 있었던 모든 환자에 서 망막앞막제거술과 백내장수술을 같이 시행하였으며, 그 결과 평균 $\log$ MAR 0.33 의 뚜렷한 시력호전이 나타났다.

망막앞막 및 백내장으로 진단되었으나 백내장수술만 시 행 받은 경우와 비교하였을 때, 망막앞막수술을 함께 시행 받은 경우 시력호전 정도에 약간의 차이가 있었으나 그 차 이는 통계적으로 유의하지 않았으며, 백내장수술만으로도 어느 정도의 시력호전을 얻을 수 있는 것으로 나타났다. 그 러나 백내장수술만 시행 받은 군의 경우 술 전 중심망막두 께가 망막앞막제거술을 함께 시행 받은 군에 비해 뚜렷하 게 더 적은 경향이 있어 이와 같은 망막 상태의 차이가 연 구 결과에 일부 영향을 미쳤을 가능성이 있다. 본 연구가 후향적 연구로 소수의 안을 대상으로 시행되었다는 점을 고려하였을 때, 망막앞막과 백내장이 함께 진단된 안을 어 떻게 치료할 것인지에 대한 보다 정확한 해답을 얻기 위해 서는 향후 추가적인 연구가 필요할 것으로 생각된다. 
망막앞막제거술만 시행 받은 11 안의 경우 시력회복의 정 도는 평균 $\log \mathrm{MAR} 0.14$ 로 백내장수술을 같이 시행한 경우 에 비해 상대적으로 적었다. 그러나 $36.4 \%$ 에서 평균 $\log \mathrm{MAR}$ 시력 0.2 이상의 회복이 나타났으며, 평균 22.1 개월의 경과 관찰기간 동안 뚜렷하게 시력이 악화된 경우는 없었다. 특 히 망막앞막으로 진단되었으나 수술 없이 경과 관찰한 안 과 비교하였을 때 시력 변화에 유의한 차이가 있었는데, 이 는 망막앞막제거술이 장기적으로 시력을 호전시키거나 유 지시키는 데에 효과가 있음을 시사하는 소견으로 생각된다.

내망막불규칙성 지수는 망막앞막의 진행에 의한 망막 내 층의 변화 정도를 정량화할 수 있는 유용한 지표로 알려져 있다. ${ }^{8}$ Cho et $\mathrm{al}^{8}$ 의 연구에서는 망막앞막수술 전 및 수술 후의 각 시점에서 측정된 내망막불규칙성 지수가 같은 시 점에 측정된 시력과 유의한 연관성이 있었으며, 더 나아가 술 전 측정된 지수가 술 후 6 개월 시력에 대한 예측인자가 될 수 있는 것으로 나타났다. 본 연구에서는 수술 전 측정 된 내망막불규칙성 지수가 더 높은 안에서 술 전 시력이 더 나쁜 경향이 있었으나 술 후 시력 및 시력의 변화량과는 유 의한 연관관계가 나타나지 않았다. 원뿔세포외절말단선 결 손의 경우 역시 망막앞막수술 후 결과와 관련된 인자로 알 려져 있으나 ${ }^{20}$ 본 연구에서는 시력 결과와 유의한 연관관계 가 나타나지 않았다. 그러나 이와 같은 결과는 백내장수술 여부 등 다양한 교란인자를 통제하지 못한 데에서 기인하 였을 가능성이 있다.

본 연구에는 다음과 같은 제한점이 있다. 첫 번째로, 본 연구는 후향적 연구이다. 백내장수술을 함께 시행 받은 안 과 망막앞막제거술만 시행 받은 안이 분석에 함께 포함되 었는데, 소수의 안을 대상으로 한 연구였기에 각 군의 임상 결과를 따로 분석하기 어려운 면이 있었다. 특히 백내장수 술 없이 망막앞막제거술만 시행 받은 경우는 11 안에 불과 하여 순수하게 망막앞막을 제거한 효과를 보다 정확하게 평가하기 위해서는 보다 많은 안을 대상으로 한 추가 연구 가 필요할 것이다. 두 번째로, 본 연구에서는 환자에 따라 수술 후 추적 관찰기간에 상당한 차이가 있었다. 망막앞막 수술 후 3 개월 이내에 대부분의 시력 회복이 나타난다는 기존의 연구 결과 ${ }^{21}$ 를 고려하였을 때, 경과 관찰기간의 차 이가 본 연구의 결과에 큰 영향을 미치지는 않았을 것으로 생각된다. 변시증은 망막전막환자의 주된 시기능 이상 중 하나로 시력과 함께 환자의 삶의 질에 큰 영향을 미치는 지 표로 알려져 있다. ${ }^{22}$ 그러나 본 연구에서는 시력에 대한 부 분만 평가하였으며, 변시증에 대한 평가는 따로 시행되지 않았다. 본 연구에는 3 가지 서로 다른 빛간섭단층촬영 기기 가 이용되었다. 한 환자에서 단일 기종으로 지속적으로 검 사를 시행하지 못하였기에 측정한 기기에 따라 중심황반두
께 측정값에 약간의 차이가 나타나 결과에 일부 영향을 미 쳤을 것으로 생각된다. 본 연구에서는 진단 혹은 수술 일이 빠른 순서대로 연구군과 같은 28 명을 각 대조군으로 선정 하였는데, 이와 같은 선정 방식에는 선택편향(selection bias) 이 관여하였을 가능성이 있어 결과의 해석에 유의해야 할 것이다. 마지막으로 본 연구에서는 망막앞막제거술 후 전 신 합병증이 나타난 경우는 없었다. 그러나 전신 합병증 발 생 유무는 환자의 진술에 의거 평가한 부분으로 실제 합병 증이 발생한 경우라 해도 환자가 진료실에서 따로 진술하 지 않은 경우 합병증의 발생 여부를 확인할 수 없었다.

요약하면 본 연구에서는 80 세 이상 고령의 특발망막앞막 환자를 대상으로 망막앞막제거술의 임상결과를 평가하였 는데, 망막앞막제거술 단독 혹은 백내장수술과의 병합수술 을 시행 받은 후 해부학적 호전과 함께 시력이 유지 혹은 호전되는 결과를 확인할 수 있었다. 또한 수술과 관련된 전 신 부작용은 나타나지 않았다. 이와 같은 본 연구의 결과를 고려하였을 때, 수술 전 전신 상태에 대한 평가와 함께 동 반 질환에 대한 적절한 관리가 이루어진다면 고령에서도 망막앞막제거술이 안전하고 유용한 방법이 될 수 있을 것 으로 생각된다.

\section{REFERENCES}

1) Kim JM, Lee H, Shin JP, et al. Epiretinal membrane: prevalence and risk factors from the Korea National Health and Nutrition Examination Survey, 2008 through 2012. Korean J Ophthalmol 2017;31:514-23.

2) Fang IM, Hsu CC, Chen LL. Correlation between visual acuity changes and optical coherence tomography morphological findings in idiopathic epiretinal membranes. Graefes Arch Clin Exp Ophthalmol 2016;254:437-44.

3) Suh MH, Seo JM, Park KH, Yu HG. Associations between macular findings by optical coherence tomography and visual outcomes after epiretinal membrane removal. Am J Ophthalmol 2009; 147: 473-80.e3.

4) Lee JW, Kim IT. Outcomes of idiopathic macular epiretinal membrane removal with and without internal limiting membrane peeling: a comparative study. Jpn J Ophthalmol 2010;54:129-34.

5) Lee P, Lee TG, Kim MS, et al. Prognostic factors in vitrectomy for macular epiretinal membrane. J Korean Ophthalmol Soc 2011;52: 1302-7.

6) Kauffmann Y, Ramel JC, Lefebvre A, et al. Preoperative prognostic factors and predictive score in patients operated on for combined cataract and idiopathic epiretinal membrane. Am J Ophthalmol 2015;160:185-92.e5.

7) Spiteri Cornish K, Lois N, Scott NW, et al. Vitrectomy with internal limiting membrane peeling versus no peeling for idiopathic full-thickness macular hole. Ophthalmology 2014;121:649-55.

8) Cho KH, Park SJ, Cho JH, et al. Inner-retinal irregularity index predicts postoperative visual prognosis in idiopathic epiretinal membrane. 
Am J Ophthalmol 2016;168:139-49.

9) $\mathrm{Bu} \mathrm{SC}$, Kuijer R, Li XR, et al. Idiopathic epiretinal membrane. Retina 2014;34:2317-35.

10) Yang HS, Hong JW, Kim YJ, et al. Characteristics of spontaneous idiopathic epiretinal membrane separation in spectral domain optical coherence tomography. Retina 2014;34:2079-87.

11) Muto T, Ide T, Chikuda M, Machida S. Vitrectomy in patients over 90 years of age. Clin Ophthalmol 2016;10:239-42.

12) Park JC, Ramasamy B, Shaw S, et al. A prospective and nationwide study investigating endophthalmitis following pars plana vitrectomy: clinical presentation, microbiology, management and outcome. $\mathrm{Br}$ J Ophthalmol 2014;98:1080-6.

13) Rizzo S, Belting C, Genovesi-Ebert F, di Bartolo E. Incidence of retinal detachment after small-incision, sutureless pars plana vitrectomy compared with conventional 20-gauge vitrectomy in macular hole and epiretinal membrane surgery. Retina 2010;30: 1065-71.

14) Chang S. LXII Edward Jackson lecture: open angle glaucoma after vitrectomy. Am J Ophthalmol 2006;141:1033-43.

15) Christensen UC, Krøyer K, Sander B, et al. Value of internal limiting membrane peeling in surgery for idiopathic macular hole stage 2 and 3: a randomised clinical trial. Br J Ophthalmol 2009;93:1005-15.

16) Miguel AI, Legris A. Prognostic factors of epiretinal membranes: a systematic review. J Fr Ophtalmol 2017;40:61-79.

17) Kim TN, Lee JE, Lee EJ, et al. Prevalence of and factors associated with lens opacities in a Korean adult population with and without diabetes: the 2008-2009 Korea National Health and Nutrition Examination Survey. PLoS One 2014;9:e94189.

18) Lee JJ, Kim KH, Shin MK, et al. Myopic shift and cataract change after lens sparing vitrectomy in patients with idiopathic epiretinal membrane in their 5 th and 6 th decade. J Korean Ophthalmol Soc 2015;56:1038-43.

19) Jung KI, Song MH, Roh YJ. Combined clear corneal phacoemulsification and vitrectomy versus two-step surgery in Korean patients with idiopathic epiretinal membrane. J Korean Ophthalmol Soc 2011;52:203-9.

20) Shimozono M, Oishi A, Hata M, et al. The significance of cone outer segment tips as a prognostic factor in epiretinal membrane surgery. Am J Ophthalmol 2012;153:698-704.e1.

21) Kim J, Rhee KM, Woo SJ, et al. Long-term temporal changes of macular thickness and visual outcome after vitrectomy for idiopathic epiretinal membrane. Am J Ophthalmol 2010;150:701-9.e1.

22) Okamoto F, Okamoto Y, Hiraoka T, Oshika T. Effect of vitrectomy for epiretinal membrane on visual function and vision-related quality of life. Am J Ophthalmol 2009;147:869-74.e1.

\section{= 국문초록 $=$}

\section{0세 이상 고령에서 시행한 특발망막앞막제거술의 임상결과}

목적: 80세 이상 초고령 환자에서 특발망막앞막제거술의 임상성적을 보고하고자 한다.

대상과 방법: 특발망막앞막으로 유리체절제술 및 망막앞막제거술을 시행 받은 56명을 대상으로 후향적 연구를 시행하였다. 80세 이상 군 $(n=28)$ 에서 수술 전 측정된 시력과 중심망막두께를 최종 추적 관찰 시의 값과 서로 비교하였다. 80 세 이상 군과 80 세 미만 군 $(n=28)$ 에서의 수술 후 시력 변화 정도를 추가적으로 비교하였다.

결과: 80 세 이상 군에서 평균 추적 관찰기간은 수술 후 $19.1 \pm 17.0$ 개월이었다. 수술 전 11안은 위수정체, 17 안은 유수정체였으며, 유수정체였던 17안 모두에서 망막앞막제거술 시 백내장수술을 함께 시행하였다. 수술 관련 합병증은 관찰되지 않았다. 수술 전 측정된 평균 logarithm of minimal angle of resolution (logMAR) 시력은 $0.75 \pm 0.30$ 이었으며, 최종 추적 관찰 시 $0.50 \pm 0.30$ 으로 호전되었 다 $(p<0.001)$. 중심망막두께는 수술 전 458.0 $\pm 79.7 \mu \mathrm{m}$ 였으며, 최종 추적 관찰 시 $367.2 \pm 83.4 \mu \mathrm{m}$ 로 감소하였다 $(p<0.001) .80$ 세 이상 군과 80 세 미만 군 사이에 수술 후 시력의 변화 정도는 유의한 차이가 없었다 $(p=0.547)$.

결론: 80세 이상 고령의 특발망막앞막환자에서 망막앞막제거술 단독 혹은 백내장수술과의 병합수술 결과 해부학적 호전과 함께 시력 이 유지 혹은 회복되었다. 이러한 결과는 고령에서도 망막앞막제거술이 유용할 수 있음을 시사한다.

〈대한안과학회지 2020;61(2):159-166〉

한재욱 / Jae Wook Han

건양대학교 의과대학 김안과병원 안과학교실

Department of Ophthalmology,

Kim's Eye Hospital,

Konyang University College of Medicine 